\title{
Profilowe zróżnicowanie form żelaza i glinu w glebach pod świerczyną górnoreglową Plagiothecio-Piccetum tatricum w Gorcach jako wskaźnik aktualnych procesów glebotwórczych
}

\begin{abstract}
Streszczenie: Celem pracy była identyfikacja procesów glebotwórczych kształtujących gleby wytworzone z pokryw zwietrzelinowych piaskowca magurskiego pod świerczyną górnoreglową Plagiothecio-Piccetum tatricum w Gorcach, na podstawie profilowego zróżnicowania zawartości niekrzemianowych form żelaza. W poziomach genetycznych 4 profili różniących się formą próchnicy i cechami morfologicznymi oznaczono zawartość form pirofosforanowych, szczawianowych i ditionitowych Fe i Al. W oparciu o nie obliczono wybrane wskaźniki pedogenezy, na podstawie których stwierdzono, że właściwości badanych gleb kształtowane były przez procesy bielicowania i brunatnienia. W glebach stanowisk, na których pokrywa roślinna charakteryzowała się dużym udziałem wietlicy alpejskiej Athyrium distentifolium silniej zaznaczone były efekty brunatnienia, a w glebach płatów zdominowanych przez borówkę czarną Vaccinium myrtillus - cechy bielicowania. Badane gleby według kryteriów Systematyki gleb Polski (2011), zaliczono do gleb brunatnych dystroficznych typowych, gleb brunatnych dystroficznych z cechami bielicowania oraz bielic typowych. Według World Reference Base for Soil Resources (IUSS Working Group WRB 2015) należą one do Dystric Cambisols i Albic Podzols.
\end{abstract}

Słowa kluczowe: formy żelaza, formy glinu, gleby brunatne, bielice, Gorce

\section{WSTĘP}

W reglu górnym Gorczańskiego Parku Narodowego, na kwaśnych skałach fliszowych serii magurskiej, pod świerczyną górnoreglową, występują gleby, w których zazwyczaj zaznaczone są w różnym stopniu efekty procesu bielicowania (Adamczyk 1966, Niemtur 1997). Wskaźnikiem aktualnie zachodzących w tych glebach procesów glebotwórczych jest rozmieszczenie $\mathrm{w}$ profilach glebowych różnych form żelaza i glinu.

Do identyfikacji procesów bielicowania i brunatnienia od wielu lat wykorzystywane są wskaźniki diagnostyczne określane na podstawie zawartości różnych form żelaza, najczęściej ekstrahowanych pirofosforanem sodu, cytrynianem sodu i szczawianem amonu (McKeague 1967, Konecka-Betley 1967, Bascomb 1968, Rapaport i Vasu 1972, Mokma 1983, Melke 1997, Karczewska i in. 1998, Chojnicki 2001, Kowalczyk i Miechówka 2001, Chojnicki i in. 2010, Kabała i in. 2010, Różański i in. 2013). Były one między innymi stosowane w celu porównania intensywności procesu bielicowania w glebach wytworzonych z różnego materiału macierzystego (Certini i in. 1998, Gruba 2001, D’Amico i in. 2008) i pod różnymi zbio- rowiskami roślinnymi (Miechówka i in. 1998, Miechówka i in. 2006, Zanelli i in.2007). Często za ich pomocą identyfikowane były zmiany zachodzące $\mathrm{w}$ glebach pod wpływem czasu (Mokma i in. 2004, Sauer i in. 2008, Dahms i in. 2012) i warunków klimatycznych (Degórski 2007, Miechówka i in. 2006). Okazały się one również przydatne dla oceny wpływu tzw. bocznego bielicowania w terenach o urozmaiconej rzeźbie terenu (Sommer i in. 2000 i 2001, Jankowski 2014) oraz (w mniejszym stopniu) dla udowodnienia poligenetycznego charakteru niektórych bielic (Zagórski 2001, Waroszewski i in. 2010 i 2015).

Celem pracy była ocena profilowego zróżnicowania zawartości niekrzemianowych form żelaza w glebach pod świerczyną górnoreglową PlagiothecioPiccetum tatricum w Gorcach, co pozwoliło na określenie dominującego procesu glebotwórczego, który je ukształtował. Oznaczenie podstawowych właściwości badanych gleb i zawartości amorficznych form żelaza i glinu umożliwiło ustalenie ich przynależności taksonomicznej, zgodnie z Systematyką gleb Polski (Systematyka gleb Polski 2011), Klasyfikacją gleb leśnych Polski (2000) i World Reference Base for Soil Resources (IUSS Working Group WRB 2015). 


\section{MATERIAŁY I METODYKA BADAŃ}

Materiał glebowy został pobrany z 4 profili glebowych różniących się formą próchnicy i zaawansowaniem procesu bielicowania, ocenionym w oparciu o występowanie lub brak makroskopowych efektów tego procesu. Badane profile zlokalizowane były na terenie Gorczańskiego Parku Narodowego, w reglu górnym, na wysokości 1200-1250 m n.p.m., na prostych, górnych odcinkach północnych lub północnozachodnich stoków o nachyleniu $15-35^{\circ}$ (tab. 1). Reprezentowały one gleby piętra klimatycznego chłodnego, w którym średnie roczne temperatury wahają się od +2 do $+4^{\circ} \mathrm{C}$, a średnie roczne opady od 1200 do $1240 \mathrm{~mm}$ (Hess 1965). Gleby te powstały z pokryw stokowych wytworzonych ze skał fliszowych serii magurskiej pod świerczyną górnoreglową Plagiothecio-Piccetum tatricum. W runie gatunkami dominującymi były borówka czarna Vaccinium myrtillus (Vacc.) i/lub wietlica alpejska Athyrium distentifolium (Ath.). Procentowy udział tych gatunków w pokrywie roślinnej płatów, których gleby były reprezentowane przez badane profile, był różny (tab. 1).

W glebach oznaczono: barwę próbek wilgotnych według skali barw Munsell'a (Munsell Soil Colour Charts 2000), skład granulometryczny metodą are- ometryczną Cassagrande'a w modyfikacji Prószyńskiego (PN-R 04032 1998), $\mathrm{pH} \mathrm{w} 1 \mathrm{~mol} \cdot \mathrm{dm}^{-3} \mathrm{KCl}$ metodą potencjometryczną, zawartość węgla organicznego metodą Tiurina (Oleksynowa i in. 1991), zawartość azotu ogólnego metodą Kjeldahla, sumę zasad wymiennych przez oznaczenie poszczególnych kationów $\left(\mathrm{Ca}^{+2}, \mathrm{Mg}^{+2}, \mathrm{~K}^{+}, \mathrm{Na}^{+}\right)$w roztworze octanu amonu o stężeniu $1 \mathrm{~mol} \cdot \mathrm{dm}^{-3}$, kwasowość hydrolityczną metodą Kappena (Lityński i in. 1976), zawartość $\mathrm{Fe}_{\mathrm{p}}, \mathrm{Al}_{\mathrm{p}} \mathrm{i} \mathrm{C}_{\mathrm{p}} \mathrm{W}$ wyciągu $0,1 \mathrm{~mol} \cdot \mathrm{dm}^{-3}$ pirofosforanu sodu o $\mathrm{pH} 10$ po 24-godzinnej ekstrakcji (McKeague 1967), zawartość $\mathrm{Fe}_{\text {ox }}$ i $\mathrm{Al}_{\mathrm{ox}}$ w wyciagu 0,2 $\mathrm{mol} \cdot \mathrm{dm}^{-3}$ szczawianu amonowego o pH 3,0 (Schwertmann 1964), zawartość $\mathrm{Fe}_{\mathrm{d}}$ i Al $\mathrm{d}_{\mathrm{d}} \mathrm{w}$ wyciągu 0,3 $\mathrm{mol} \cdot \mathrm{dm}^{-3}$ cytrynianu sodu $\mathrm{z}$ ditionitem i kwaśnym węglanem sodu według metody Mehra i Jacksona w modyfikacji Schwertmanna (1964). W wyciagach oznaczono zawartość Fe metoda AAS, a zawartość Al metodą ICP. Obliczono zawartość żelaza amorficznego niezwiązanego $\mathrm{z}$ substancją organiczną $\left(\mathrm{Fe}_{\mathrm{ac}}=\mathrm{Fe}_{\mathrm{ox}}-\mathrm{Fe}_{\mathrm{p}}\right)$ i żelaza krystalicznego $\left(\mathrm{Fe}_{\mathrm{kr}}=\mathrm{Fe}_{\mathrm{d}}-\mathrm{Fe}_{\mathrm{ox}}\right)$ oraz wybrane wskaźniki uznane w literaturze gleboznawczej za pomocne w ocenie procesów glebotwórczych: $\mathrm{Fe}_{\mathrm{o}} / \mathrm{Fe}_{\mathrm{d}}, \mathrm{C}_{\mathrm{p}} /\left(\mathrm{Fe}_{\mathrm{p}}+\mathrm{Al}_{\mathrm{p}}\right) \mathrm{m}$ i $\left(\mathrm{Al}_{\mathrm{ox}}+0,5 \mathrm{Fe}_{\mathrm{ox}}\right)$ w poziomie $\mathrm{B} /\left(\mathrm{Al}_{\mathrm{ox}}+0,5 \mathrm{Fe}_{\mathrm{ox}}\right) \mathrm{W}$ poziomie $\mathrm{A}$ lub $\mathrm{E}$.

TABELA 1. Lokalizacja obiektu badań i typologia gleb TABLE 1. Location of sampling sites and soils typology

\begin{tabular}{|c|c|c|c|c|c|c|c|}
\hline \multirow{2}{*}{$\begin{array}{l}\text { Nr } \\
\text { profilu } \\
\text { Profile } \\
\text { No. }\end{array}$} & \multirow{2}{*}{$\begin{array}{l}\text { Współrzędne GPS, } \\
\text { wysokość m n.p.m. } \\
\text { ekspozycja } \\
\text { PGS position, elevation b.s.1., } \\
\text { slope exposition }\end{array}$} & \multicolumn{2}{|c|}{$\begin{array}{l}\text { Roślinność runa }^{1} \\
\text { Vegetation } \\
\text { undergrowth }\end{array}$} & \multirow[t]{2}{*}{$\begin{array}{l}\text { Forma } \\
\text { próchnicy } \\
\text { Humus type }\end{array}$} & \multicolumn{3}{|c|}{$\begin{array}{l}\text { Jednostki taksonomiczne gleb według } \\
\text { Soil taxonomic units according to }\end{array}$} \\
\hline & & $\begin{array}{l}\% \\
\text { Ath. }\end{array}$ & $\begin{array}{l}\text { \% } \\
\text { Vacc. }\end{array}$ & & $\begin{array}{l}\text { Systematyka gleb } \\
\text { Polski (2011) }\end{array}$ & $\begin{array}{l}\text { KGLP } \\
(2000)^{3}\end{array}$ & $\begin{array}{l}\text { WRB } \\
(2015)^{4}\end{array}$ \\
\hline 1 & $\begin{array}{l}\mathrm{N} 49^{\circ} 32^{\prime} 52^{\prime \prime} \text { E } 20^{\circ} 7^{\prime} 16^{\prime \prime} \\
1205,15^{\circ} \mathrm{N}\end{array}$ & 95 & 5 & Hemimoder & $\begin{array}{l}\text { Gleba brunatna } \\
\text { dystroficzna } \\
\text { typowa }\end{array}$ & $\begin{array}{l}\text { Gleba } \\
\text { brunatna } \\
\text { kwaśna }\end{array}$ & $\begin{array}{l}\text { Dystric } \\
\text { Endoskeletic } \\
\text { Cambisol } \\
\text { (Loamic, Humic) }\end{array}$ \\
\hline 2 & $\begin{array}{l}\text { N 4932'33" E } 20^{\circ} 8^{\prime} 35^{\prime \prime}, \\
1200,15^{\circ} \mathrm{N}\end{array}$ & 85 & 20 & Eumor & $\begin{array}{l}\text { Gleba brunatna } \\
\text { dystroficzna } \\
\text { z cechami } \\
\text { bielicowania } \\
\end{array}$ & $\begin{array}{l}\text { Gleba } \\
\text { brunatna } \\
\text { bielicowa }\end{array}$ & $\begin{array}{l}\text { Dystric } \\
\text { Endoskeletic } \\
\text { Cambisol } \\
\text { (Loamic, Humic) }\end{array}$ \\
\hline 3 & $\begin{array}{l}\text { N } 49^{\circ} 32^{\prime} 59^{\prime \prime} \text { E } 20^{\circ} 09^{\prime} 22^{\prime \prime}, \\
1250,35^{\circ} \mathrm{NW}\end{array}$ & 75 & 25 & Hemimor & $\begin{array}{l}\text { Gleba brunatna } \\
\text { dystroficzna } \\
\text { z cechami } \\
\text { bielicowania } \\
\end{array}$ & $\begin{array}{l}\text { Gleba } \\
\text { brunatna } \\
\text { bielicowa }\end{array}$ & $\begin{array}{l}\text { Dystric Cambisol } \\
\text { (Siltic, Humic) }\end{array}$ \\
\hline 4 & $\begin{array}{l}\text { N 49॰32'46" E } 20^{\circ} 09^{\prime} 06^{\prime \prime}, \\
1230,25^{\circ} \mathrm{NNW}\end{array}$ & 0 & 95 & Humimor & Bielica typowa & $\begin{array}{l}\text { Gleba } \\
\text { bielicowa } \\
\text { bielica } \\
\text { właś ciwa }\end{array}$ & $\begin{array}{l}\text { Skeletic Folic } \\
\text { Albic Podzol } \\
\text { (Arenic) }\end{array}$ \\
\hline
\end{tabular}




\section{WYNIKI BADAŃ I DYSKUSJA}

Barwa badanych gleb charakteryzowała się najczęściej odcieniem 10YR lub 7,5YR. Barwę diagnostyczną dla materiału albic stwierdzono jedynie w poziomie AE profilu 4, a dla poziomu spodic $\mathrm{w}$ poziomach Bh profilu 3 i Bhs profilu 4. Pozostałe poziomy wzbogacenia, $\mathrm{z}$ wyjątkiem poziomu $\mathrm{Bw}$ profilu 2, miały barwę o odcieniu 10YR oraz jasności i natężeniu w granicach 4-6 (tab. 2). Analizowane gleby należały do następujących grup granulometrycznych: piaski, pyły i gliny (tab. 2) (PTG 2009). Charakteryzowały się bardzo silnie kwaśnym odczynem, znaczną zawartością węgla organicznego, dużą pojemnością wymienną kationową i niskim stopniem wysycenia kompleksu sorpcyjnego kationami zasadowymi (tab. 2).

W poziomach genetycznych profilu 1 i 2 zawartość $\mathrm{Fe}_{\text {ox }}$ była wyrównana, ale różniły się one składem tej frakcji (tab. 3). W poziomie B zawartość $\mathrm{Fe}_{\mathrm{p}}$ była większa, a $\mathrm{Fe}_{\mathrm{ac}}$ mniejsza, niż w pozostałych poziomach. Może to świadczyć o przemieszczaniu połączeń próchniczno-żelazistych w profilu. Rozmieszczenie $\mathrm{Al}_{\mathrm{ox}} \mathrm{w}$ tych profilach było zróżnicowane. W profilu 1 zawartość tej frakcji była większa w poziomie A niż w poziomie B, natomiast w profilu 2 jej rozmieszczenie było odwrotne (tab. 3 ). W obydwu profilach zróżnicowanie zawartości $\mathrm{Al}_{\mathrm{p}} \mathrm{w}$ poziomach A i B było mniejsze niż w glebach brunatnych pod świerczyną górnoreglową w Babiogórskim Parku Narodowym (Kowalczyk i Miechówka 2001). Otrzymane wyniki nie pozwalają więc na potwierdzenie hipotezy, że pierwszą fazą procesu bielicowania jest przemieszczanie glinu, a dopiero później uruchamiane jest żelazo (Rapaport i Vasu 1972). Na podkreślenie zasługuje wyraźnie wyższa zawartość $\mathrm{Fe}_{\mathrm{d}} \mathrm{w}$ poziomie $\mathrm{B}$ profilu 1, warunkowana obecnością $\mathrm{Fe}_{\mathrm{kr}}$. Akumulacja $\mathrm{Fe}_{\mathrm{kr}}$ jest typowa dla większości gleb brunatnych eutroficznych, ale może nie następować w glebach wytworzonych z utworów kwaśnych (Melke 1997).

W poziomach genetycznych profili 3 i 4 zawartość analizowanych form $\mathrm{Fe}$ i Al była znacznie bardziej zróżnicowana niż w profilach 1 i 2 (tab. 3). Zawartość $\mathrm{Fe}_{\mathrm{d}}$ w poziomie B profilu 3 była blisko 2krotnie, a w profilu 4 ponad 13-krotnie większa w porównaniu z poziomami AE. W składzie $\mathrm{Fe}_{\mathrm{d}}$ przeważało $\mathrm{Fe}_{\text {ox }}$, przy czym w profilu 3 stanowiły go głównie formy amorficzne $\mathrm{Fe}_{\mathrm{ac}}$ (nieorganiczne i niekrystaliczne), a w profilu 4 przeważnie formy organiczne $\left(\mathrm{Fe}_{\mathrm{p}}\right)$ (tab. 3), co może świadczyć o bardziej zaawansowanym procesie bielicowania w profilu 4. W profilach tych również zawartość $\mathrm{Al}_{\text {ox }}$ była wyraźnie zróżnicowana, przy czym największa wystę- powała w poziomach głębiej leżących niż poziomy, które charakteryzowały się maksymalną zawartością $\mathrm{Fe}_{\text {ox }}$. Zależność taka była obserwowana również $\mathrm{w}$ innych glebach górskich $\mathrm{z}$ zaawansowanym procesem bielicowania (Kowalczyk i Miechówka 2001, Kabała $i$ in. 2010).

Dla określenia wpływu procesów bielicowania i brunatnienia na kształtowanie gleb najczęściej stosuje się: wskaźnik Schwertmana, zwany inaczej wskaźnikiem aktywności żelaza, obliczany jako $\mathrm{Fe}_{\mathrm{ox}} / \mathrm{Fe}_{\mathrm{d}}$, kryteria oparte o zawartość w glebach $\mathrm{C}_{\mathrm{p}}, \mathrm{Fe}_{\mathrm{p}}$ i Al $l_{p}$ definiowane dla poziomu spodic przez Mokmę (1983) - powszechnie w przeszłości stosowane w różnych klasyfikacjach gleb (między innymi w Systematyce gleb Polski 1989) oraz wskaźnik iluwiacji obliczany jako stosunek zawartości $\mathrm{Al}_{\mathrm{ox}}+0,5 \mathrm{Fe}_{\mathrm{ox}}$ w poziomie B i A lub E, wprowadzony z systemem World Reference Base for Soil Resources, a obecnie wykorzystywany w wielu klasyfikacjach gleb, w tym w Klasyfikacji gleb leśnych Polski (2000) i Systematyce gleb Polski (2011), dla wyodrębnienia poziomu spodic.

Wartości wskaźnika Schwertmana w poziomach mineralnych badanych gleb wahały się w granicach $0,58-0,94$ (tab. 3). Jedynie w poziomie B profilu 1 jego wartość $(0,59)$ mieściła się $w$ granicach $0,25-$ 0,60 przyjętych przez Blume i Schwertmana (1969) jako diagnostyczne dla poziomu cambic. Podobne wartości charakteryzowały też poziomy BC profili 2 i 3 (odpowiednio 0,58 i 0,60 ). W pozostałych poziomach były one dużo wyższe, co świadczy o dużej aktywności w nich żelaza (tab. 3).

Zawartość form pirofosforanowych $\mathrm{C}_{\mathrm{p}}+\mathrm{Fe}_{\mathrm{p}}+\mathrm{Al}_{\mathrm{p}}$ we wszystkich badanych poziomach była stosunkowo duża i przekraczała $0,5 \%$ (tab. 3). W profilu 1 zmniejszała się ona wraz z głębokością, natomiast w profilach 2-4 osiagała maksimum w poziomach $B$. Największą różnicę pomiędzy zawartością kompleksów próchniczno-żelazistych w poziomie $\mathrm{B}$ i AE stwierdzono w profilu 4 (tab. 3). Stosunek molowy $\mathrm{C}_{\mathrm{p}}$ ' $\mathrm{Fe}_{\mathrm{p}}+\mathrm{Al}_{\mathrm{p}}$ obliczony dla poziomów $\mathrm{A}$ w profilach 1 i 2 nie przekroczył wartości 25 , granicznej dla gleb podlegających procesowi bielicowania, natomiast w profilach 3 i 4 przekroczył tę wartość, co świadczy o obecności ruchliwych kompleksów próchniczno-mineralnych (tab. 3). Wartość tego wskaźnika dla poziomu B w profilu 1 była mniejsza od 5,8 natomiast w przypadku pozostałych profili jego wartości charakteryzujące poziomy B były większe od 5,8. Wszystkie kryteria oparte o zawartość form pirofosforanowych węgla, żelaza i glinu podane dla poziomu spodic przez Mokmę (1983), były spełnione w odniesieniu do profili 3 i 4. Gleby reprezentowane przez te profile według wcześniejszych systematyk, 
TABELA 2. Wybrane właściwości badanych gleb

TABLE 2. Selected properties of the investigated soils

\begin{tabular}{|c|c|c|c|c|c|c|c|c|c|c|c|c|c|}
\hline \multirow{2}{*}{$\begin{array}{l}\mathrm{Nr} \\
\text { profilu } \\
\text { Profile } \\
\text { No }\end{array}$} & \multirow{2}{*}{$\begin{array}{l}\text { Poziom } \\
\text { glebowy } \\
\text { Soil } \\
\text { horizon }\end{array}$} & \multirow{2}{*}{$\begin{array}{l}\text { Głębokość } \\
\text { Depth } \\
\mathrm{cm}\end{array}$} & \multirow[t]{2}{*}{$\begin{array}{l}\text { Barwa }^{1} \\
\text { Color }^{1}\end{array}$} & \multicolumn{4}{|c|}{$\begin{array}{l}\% \text { frakcji o średnicy w } \mathrm{mm} \\
\% \text { fraction with diameter in } \mathrm{mm}\end{array}$} & \multirow{2}{*}{$\begin{array}{l}\text { Uziarnienie wg PTG } \\
(2009)^{2} \\
\text { Texture according } \\
\text { to PTG }(2009)^{2}\end{array}$} & \multirow[t]{2}{*}{$\mathrm{pH}_{\mathrm{KCl}}$} & \multirow{2}{*}{$\begin{array}{l}\text { Corg } \\
\mathrm{g} \cdot \mathrm{kg}^{-1}\end{array}$} & \multirow[t]{2}{*}{$\mathrm{C}: \mathrm{N}$} & \multirow{2}{*}{$\begin{array}{l}\text { PWKpot }^{3} \\
\text { CEC }^{3} \\
\mathrm{cmol}(+) \cdot \mathrm{kg}^{-1}\end{array}$} & \multirow{2}{*}{$\begin{array}{l}\mathrm{V}^{4} \\
\mathrm{BS}^{4} \\
\%\end{array}$} \\
\hline & & & & $>2$ & $2-0,05$ & $0,05-0,002$ & $<0,002$ & & & & & & \\
\hline \multirow[t]{4}{*}{1} & A1 & $1-5$ & 7,5 YR $1,7 / 1$ & 0 & - & - & - & - & 3,4 & 110,5 & 16,8 & 43,58 & 6,1 \\
\hline & A2 & $5-20$ & 10YR 3/4 & 0 & - & - & - & - & 3,6 & 30,9 & 17,7 & 14,37 & 8,1 \\
\hline & Bw & $20-45$ & $10 \mathrm{YR} 4 / 4$ & 30 & 58 & 35 & 7 & (gp) (SL) & 3,9 & 12,7 & 12,4 & 7,72 & 10,6 \\
\hline & $\mathrm{BC}$ & $45-74$ & 10 YR 5/6 & 95 & 60 & 34 & 6 & (gp) (SL) & 3,9 & 8,5 & 9,8 & 7,21 & 12,6 \\
\hline \multirow[t]{6}{*}{2} & Olf & $0-3$ & - & 0 & - & - & - & - & 3,0 & 317,3 & 16,0 & 132,23 & 6,4 \\
\hline & $\mathrm{Oh}$ & $3-6$ & $10 \mathrm{YR} 2 / 2$ & 0 & - & - & - & - & 3,0 & 125,4 & 15,8 & 59,71 & 3,8 \\
\hline & $\mathrm{AE}$ & $6-10$ & $10 \mathrm{YR} 4 / 2$ & 0 & 50 & 45 & 5 & (gp) (SL) & 3,5 & 24,0 & 11,8 & 12,13 & 6,0 \\
\hline & B & $10-18$ & 10YR 5/6 & 0 & 54 & 41 & 5 & gp) (SL) & 3,9 & 16,7 & 10,3 & 8,67 & 5,5 \\
\hline & $\mathrm{Bw}$ & $18-40$ & $2,5 \mathrm{Y} 4 / 6$ & 30 & 55 & 40 & 5 & (gp) (SL) & 3,9 & 12,3 & 11,2 & 7,75 & 7,1 \\
\hline & $\mathrm{BC}$ & $40-72$ & $2,5 Y 5 / 4$ & 95 & 59 & 37 & 4 & (gp) (SL) & 4,0 & 6,6 & 10,3 & 6,85 & 9,5 \\
\hline \multirow[t]{6}{*}{3} & $\mathrm{Oh}$ & $2-4$ & 7,5YR 1,7/1 & 0 & - & - & - & - & 2,7 & 251,4 & 14,6 & 76,42 & 4,2 \\
\hline & $\mathrm{AE}$ & $4-7$ & 7,5 YR $3 / 3$ & 0 & 30 & 63 & 7 & (pyg) (SiL) & 2,8 & 62,7 & 14,9 & 21,99 & 3,2 \\
\hline & $\mathrm{Bh}$ & $7-12$ & $7,5 \mathrm{YR} 3 / 2$ & 0 & 39 & 51 & 10 & (pyg) SiL & 3,1 & 32,4 & 11,2 & 18,96 & 3,5 \\
\hline & Bwg & $12-46$ & 10YR 5/5 & 0 & 38 & 54 & 8 & (pyg) SiL & 4,0 & 13,7 & 8,1 & 8,18 & 4,6 \\
\hline & $\mathrm{BC}$ & $46-68$ & 10YR 6/6 & 0 & 35 & 57 & 8 & (pyg) SiL & 4,1 & 11,8 & 9,1 & 7,43 & 11,1 \\
\hline & $\mathrm{C}$ & $68-100$ & 10YR 6/6 & 95 & 33 & 61 & 6 & (pyg) SiL & 4,1 & 10,0 & 7,8 & 6,80 & 7,3 \\
\hline \multirow[t]{5}{*}{4} & Olf & $1-5$ & 7,5YR 1,7/1 & 0 & - & - & - & - & 2,8 & 346,3 & 19,3 & 135,30 & 8,0 \\
\hline & Oh & $5-12$ & 10YR 1,7/1 & 0 & - & - & - & - & 2,6 & 134,0 & 16,8 & 50,31 & 4,6 \\
\hline & $\mathrm{AE}$ & $12-19$ & 10YR 5/2 & 0 & 67 & 28 & 5 & (gp) (LS) & 2,7 & 30,3 & 16,2 & 11,68 & 5,0 \\
\hline & Bhs & $19-30$ & 7,5YR $2 / 3$ & 60 & 72 & 26 & 2 & (pg) (SL) & 3,3 & 42,8 & 17,1 & 23,55 & 3,2 \\
\hline & $\mathrm{C}$ & $30-65$ & 10YR 5/5 & 90 & 77 & 21 & 2 & (pg) (SL) & 4,0 & 15,2 & 14,8 & 7,59 & 5,1 \\
\hline
\end{tabular}

${ }^{1}$ Według skali barw Munsella (Munsell Soil Colour Charts 2000); according to Munsell Soil Color Charts (2000).

${ }^{2}$ Uziarnienie: gp - glina piaszczysta, pyg - pył gliniasty, pg - piasek gliniasty; texture: SL - sandy loam, SiL - silty loam, LS - loamy sand.

Pojemność sorpcyjna; cation exchange capacity.

${ }^{4}$ Stopień wysycenia kompleksu sorpcyjnego kationami zasadowymi; base cation saturation. 


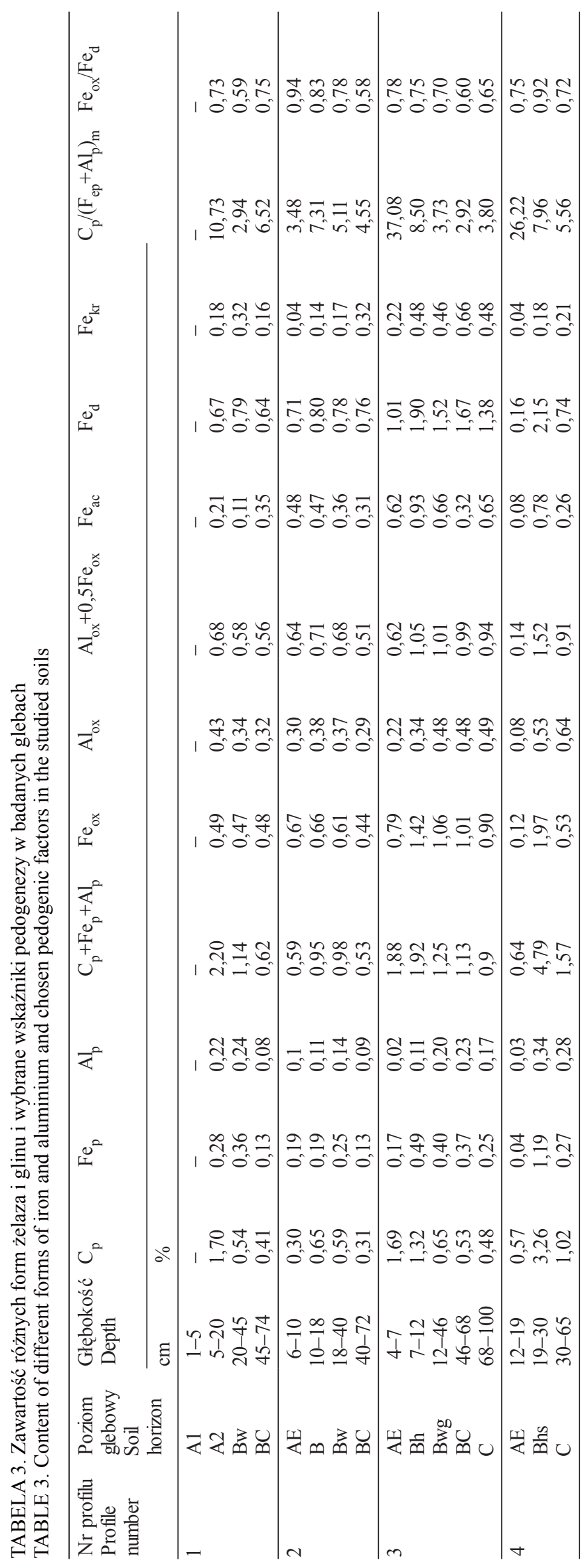

w tym Systematyki gleb Polski (1989), byłyby zaliczone do gleb bielicowych lub bielic. Badania przeprowadzone przez Grubę (2001) na terenie Beskidu Żywieckiego, pozwoliły na zaliczenie do gleb bielicoziemnych, według wskaźników Mokmy (1983), tylko jednego spośród dwudziestu profili gleb wytworzonych z piaskowca magurskiego. Na tej podstawie Gruba (2001) uznał, że gleby te sa ,mniej podatne na bielicowanie” pod wpływem drzewostanów świerkowych, w porównaniu z glebami, których skałą macierzystą są piaskowce istebniańskie i godulskie.

Zawartość $\mathrm{Al}_{\text {ox }}+0,5 \mathrm{Fe}_{\text {ox }}$ we wszystkich poziomach mineralnych badanych gleb, z wyjątkiem poziomu AE profilu 4, przekraczała wartość $0,5 \%$, uznawaną współcześnie za diagnostyczną dla poziomu spodic (tab. 3). Wartości wskaźnika iluwiacji wahały się od 0,85 (profil 1 - brak przemieszczania), poprzez 1,11 (profil 2 - niewielkie przemieszczanie), 1,69 (profil 3 - wyraźna iluwiacja) do 10,86 (profil 4 - bardzo silna iluwiacja charakterystyczna dla bielic). Jedynie w profilu 4 zawartość $\mathrm{Al}_{\mathrm{ox}}+0,5 \mathrm{Fe}_{\mathrm{ox}}$ była ponad dwukrotnie wyższa $\mathrm{w}$ poziomie $\mathrm{B}$ aniżeli $\mathrm{w}$ poziomie $\mathrm{AE}$ i tylko w tym profilu poziom B, według kryteriów Systematyki gleb Polski (2011), może być uznany za poziom spodic. Należy zaznaczyć, że w profilu tym nad poziomem spodic znajduje się poziom spełniający kryteria poziomu albic podane w Systematyce gleb Polski (2011), zarówno odnoszące się do barwy i właściwości fizykochemicznych, jak i zawartości form szczawianowych glinu i żelaza. Według World Reference Base for Soil Resources (IUSS Working Group WRB 2015) poziom Bhs profilu 4 również bez uwzględnienia wskaźników obliczonych na podstawie zawartości $\mathrm{Fe}_{\text {ox }}$ i $\mathrm{Al}_{\text {ox }}$ zostałby zakwalifikowany jako poziom diagnostyczny spodic, ponieważ wymagania diagnostyczne dla tego poziomu w przypadku występowanie nad nim poziomu zbudowango z materiału albic (definiowanego tylko według barwy) nie obejmują diagnostycznej zawartości form szczawianowych żelaza i glinu.

Przemieszczanie się kompleksów próchniczomineralnych nastąpiło również w profilach 2 i 3 , dlatego gleby te zaliczono do podtypu gleby brunatne dystroficzne z cechami bielicowania. Profil 1, w którym nastapiło jedynie niewielkie przemieszczenie $\mathrm{Fe}_{\mathrm{p}}$, sklasyfikowano jako glebę brunatną dystroficzną typową (tab. 1).

Adamczyk (1966) w części regla górnego należącej do zlewni potoków Jaszcze i Jamne w Gorcach za dominujące uznał gleby bielicowe, ale zaznaczył, że wśród nich występują mniejsze lub 
większe płaty „gleb skrytobielicowych”, które odpowiadają glebom ,pseudobrunatnym" opisanym przez Strzemskiego (1953). Podana przez tych autorów charakterystyka gleb skrytobielicowych (pseudobrunatnych) odpowiada glebom reprezentowanym przez profile 1 i 2 . Według propozycji podziału bielic górskich podanego przez Kabałę i współpracowników (2012) nie mogą one być jednak zaliczone do podtypu skrytobielice, ponieważ poziom iluwialny tych gleb nie spełnia wszystkich kryteriów poziomu spodic (Systematyka gleb Polski 2011). Kryteriów tych nie spełnia również poziom iluwialny profilu 3.

Zaprezentowane wyniki badań mogą wskazywać również na znaczny wpływ roślinności runa świerczyny górnoreglowej na procesy glebotwórcze. Można przypuszczać, że duży udział wietlicy alpejskiej Athyrium distentifolium $\mathrm{w}$ pokrywie roślinnej może powodować zahamowanie procesu bielicowania. Podobny związek pomiędzy roślinnością a przemieszczaniem w glebach form pirofosforanowych $\mathrm{Fe}$ i Al stwierdzono w świerczynach górnoreglowych Babiogórskiego Parku Narodowego (Miechówka i in. 1998). Przyczyną inhibitowania ruchliwości glinu i żelaza, może być wykazany przez innych badaczy (Tủma $\mathrm{i}$ in. 2012, 2014), wpływ Athyrium distentifolium na biologiczną aktywność gleby i jej $\mathrm{pH}$, w wyniku czego następuje zmniejszenie miąższości poziomów ektopróchnicznych i powstanie materii organicznej o niższym stosunku C:N, w porównaniu z glebami spod Vaccinium myrtillus (tab. 1,2).

\section{WNIOSKI}

1. Gleby górnoreglowe Gorców charakteryzują się znaczną zawartością i aktywnością niekrzemianowych form żelaza i glinu, których profilowe zróżnicowanie jest efektem procesów bielicowania i brunatnienia.

2. Gleby pod świerczyną górnoreglową PlagiothecioPiccetum tatricum w Gorcach, w oparciu o kryteria Systematyki gleb Polski (2011), zaliczono do gleb brunatnych dystroficznych typowych, gleb brunatnych dystroficznych z cechami bielicowania i bielic typowych.

3. Rozmieszczenie form pirofosforanowych żelaza i glinu w profilach gleb brunatnych dystroficznych świadczy o mniej lub bardziej intensywnym przemieszczaniu rozpuszczalnych kompleksów próchniczno-mineralnych.

4. Znaczny udział wietlicy alpejskiej Athyrium distentifolium $\mathrm{w}$ runie świerczyny górnoreglowej może być czynnikiem sprzyjającym występowaniu gleb brunatnych w reglu górnym.

\section{LITERATURA}

Adamczyk B., 1966. Studia nad kształtowaniem się związków pomiędzy podłożem skalnym a glebą. Cz. II. Gleby leśne wytworzone z utworów fliszowych płaszczowiny magurskiej w Gorcach. Acta Agraria et Silvestra 6: 4-48.

Bascomb C.L., 1968. Distribution of pyrophosphate-extractable iron and organic carbon in soils of various groups. Journal of Soil Science 19(2): 251-268.

Blume H.P., Schwertmann U., 1969. Genetic evaluation of profile distribution of aluminium, iron, and manganese oxides. Soil Science Society of America Journal 33: 438-44.

Certini G., Ugolini F.C., Corti G., Agnelli A., 1998. Early stages of Podzolization under Corsican pine (Pinus nigra Arn. ssp. laurico). Geoderma 83: 103-125.

Chojnicki J., 2001. Formy żelaza w madach środkowej Doliny Wisły. Roczniki Gleboznawcze - Soil Science Annual 52(supl.): 97-107.

Chojnicki J., Brzozowska A., Hryciuk A., Marczak R., 2010. Iron, aluminum and manganese forms as indicators of selected soilforming processes in soils of the "Rybitew" reservation in Kampinos National Park. Roczniki Gleboznawcze - Soil Science Annual 61(2): 29-36.

Dahms D., Favilli F., Krebs R., Egli M., 2012. Soil weathering and accumulation rates of oxalate-extractable phases from alpine chronosequences of up to $1 \mathrm{Ma}$ in age. Geomorphology 151-152: 99-113.

D’Amico M., Julitta F., Previtali F., Cantelli D., 2008. Podzolization over ophiolitic materials in the western Alps (Natural Park of Mont Avic, Aosta Valley, Italy). Geoderma 146: 129137.

Degórski M., 2007. Spatial Variability in Podzolic Soils of Central and Northern Europe EPA/600/R-07/059: 1-175.

Gruba P., 2001. Rozmieszczenie kompleksów żelazisto-próchnicznych w glebach brunatnych wytworzonych z piaskowców. Roczniki Gleboznawcze - Soil Science Annual 52(supl.): 127 133.

IUSS Working Group WRB, 2015. World Reference Base for Soil Resources 2014, update 2015. International soil classification system for naming soils and creating legends for soil maps. World Soil Resources Reports No. 106. FAO, Rome.

Hess M., 1965. Piętra klimatyczne w polskich Karpatach Zachodnich. Zeszyty Naukowe UJ, Prace Geograficzne 12.

Jankowski M., 2014. The evidence of lateral podzolization in sandy soils of Northern Poland. Catena 112: 139-147.

Kabała C., Waroszewski J., Szopka K., Bogacz A., 2010. Geneza, właściwości i rozprzestrzenienie stagnobielic w Sudetach. Roczniki Gleboznawcze - Soil Science Annual 59(4): 78-92.

Kabała C., Waroszewski J., Bogacz A., Łabaz B., 2012. O specyfice bielic górskich. Roczniki Gleboznawcze - Soil Science Annual 63, 2: 55-64.

Karczewska A., Bartoszewska K., Szerszeń L., 1998. Żelazo w wybranych profilach gleb wytworzonych z piaskowców na terenie Parku Narodowego Gór Stołowych. Zeszyty Problemowe Postępów Nauk Rolniczych 464: 201-210.

Klasyfikacja gleb leśnych Polski, 2000. Centrum Informacyjne Lasów Państwowych, Warszawa: 1-123.

Kowalczyk E., Miechówka A., 2001. Klasyfikacja kwaśnych gleb Babiogórskiego Parku Narodowego na podstawie profilowego rozmieszczenia różnych form żelaza. Roczniki Gleboznawcze - Soil Science Annual 52(supl.): 127-133. 
Konecka-Betley K., 1967. Zagadnienie żelaza w procesie glebotwórczym. Dział Wydawnictw SGGW, Warszawa: 1-69.

Lityński T., Jurkowska H., Gorlach E., 1976. Analiza chemiczno-rolnicza. PWN, Warszawa: 129-132.

McKeague J.A., 1967. An evaluation of 0,1 M pyrophosphate and pyrophosphate-dithionite in comparison with oxalate as extractants of the accumulation products in Podzols and some other soils. Canadian Journal of Soil Science 47: 95-99.

Melke J., 1997. Niektóre prawidłowości w składzie chemicznym gleb brunatnych różnych regionów geograficznych. Rozprawy habilitacyjne 56, Wydział Biologii i Nauk o Ziemi, Wydawnictwo UMCS, Lublin: 1-121.

Miechówka A., Niemyska-Łukaszuk J., Nicia P., Kowalczyk E., 1998. Charakterystyka gleb pod zbiorowiskami: Dentario glandulosae-Fagetum athyrietosum alpestris i Piceetum tatricum athyrietosum alpestris w Babiogórskim Parku Narodowym. Zeszyty Problemowe Postępów Nauk Rolniczych 464: 6573.

Miechówka A., Zadrożny P., Kowalczyk E., 2006. Podzol soils of different climatic and vegetation belts of the Babiogórski National Park. Polish Journal of Soil Science 39, 1: 73-79.

Mokma D.L., 1983. New chemical criteria for defining the spodic horizon. Soil Science Society of America Journal, 47: 972976.

Mokma D.L., Yli-Halla M., Lindqvist K., 2004. Podzol formation in sandy soils of Finland. Geoderma 120: 259-272.

Munsell soil color charts. 2000. Gretag Macbeth, New Windsor, NY.

Niemtur S., 1997. Skażenie antropogeniczne ekosystemów leśnych w Gorczańskim Parku Narodowym. Prace Instytutu Badawczego Leśnictwa ser. A 835: 1-121.

Oleksynowa K., Tokaj J., Jakubiec J., 1991. Przewodnik do ćwiczen z gleboznawstwa i geologii. Cz. II. [red.] T. Komornicki. Metody laboratoryjne analizy gleb. Skrypty AR w Krakowie: $1-134$.

PN-R 04032. 1998. Gleby i utwory mineralne. Pobieranie próbek i oznaczanie skladu granulometrycznego. Polski Komitet Normalizacyjny; 2 stycznia 1998 r. (Uchwała nr 1/98-0).

Polskie Towarzystwo Gleboznawcze, 2009. Klasyfikacja uziarnienia gleb i utworów mineralnych - PTG 2008. Roczniki Gleboznawcze - Soil Science Annual 60(2): 5-16.

Rapaport K., Vasu A., 1972. Contribution to the knowledge of podzolic soils by a comparative study of acid brown, brown podzolic and brown cryptopodzolic soils of Lotru Basin (South Carpathians). First National Soil Science Congress, Sofia 1972: 441-447.

Różański S., Bartkowiak A., Jaworska H., 2013. Forms of iron as an indicator of pedogenesis in profiles of selected soil types of the northern area of kujawsko-pomorskie province, Poland. Roczniki Gleboznawcze - Soil Science Annual 64(3): 98105.
Sauer D., Schülli-Maurer I., Sperstad R., Sorensen R., Stahr K., 2008. Podzol development with time in sandy beach deposits in southern Norway. Journal of Plant Nutrition and Soil Science 171: 483-497.

Schwertmann U., 1964. Differenzierung der Eisenoxide des Bodens durch Extraktion mit Ammoniumoxalat-Lösung. Z. Pflanzenernähr. Düng. Bodenkd. 105: 194-202.

Sommer M., Halm D., Weller U., Zarei M., Stahr K., 2000. Lateral Podzolization in a granite landscape. Soil Science Society of America Journal 64: 1434-1442.

Sommer M., Halm D., Geisinger C., Andruschkewitsch I., Zarei M., Stahr K., 2001. Lateral podzolization in a sandstone catchment. Geoderma 103: 231-247.

Strzemski M., 1953. Problem typologii górskich gleb leśnych. Sylwan 97, 1: 3-11.

Systematyka gleb Polski, 1989. Roczniki Gleboznawcze - Soil Science Annual 40(3-4): 1-150.

Systematyka gleb Polski, 2011. Roczniki Gleboznawcze - Soil Science Annual 62(3): 1-193.

Tůma I., Fiala K., Zahora J., 2012. The role of Athyrium distentifolium in reduction of soil acidification and base cation losses due to acid deposition in a deforested mountain area. Plant Soil 354(1-2): 107-120.

Tůma D., Tůmova J., Zahora J., 2014. The biological activity of soil in Norway spruce forests and in fern Athyrium distentifolium Tausch ex Opiz stands on deforested pollutedsites in the Beskydy Mts. Beskydy 7(1): 9-20.

Waroszewski J., Kabała C., Turska A., 2010. Specyficzne właściwości gleb Kowarskiego Grzbietu w Karkonoszach. Opera Corcontica 47, Suppl. 1: 47-56.

Waroszewski J., Malkiewicz M., Mazurek R., Labaz B., Jezierski P., Kabała C., 2015. Lithological discontinuities in Podzols developed from sandstone cover beds in the Stolowe Mountains (Poland). Catena 126: 11-19.

Zagórski Z., 2001. Formy żelaza jako wskaźniki procesów pedoi litogenezy w glebach niecałkowitych. Roczniki Gleboznawcze - Soil Science Annual 52(2): 87-96.

Zanella A., Jabiol B., Ponge J.F., Sartori G., de Waal R., van Delft B., Graefe U., Cools N., Katzensteiner K., Hager H., Englisch M., Brethes A., Broll G., Gobat J.M., Brun J.J., Milbert G., Kolb E., Wolf U., Frizzera L., Galvan P., Kolli R., Baritz R., Kemmers R., Vacca A., Serra G., Banas D., Garlato A., Chersich S., Klimo E., Langohr R., 2011. European Humus Forms Reference Base, 56, http://hal.archives-ouvertes.fr/docs/00/56/17/95/PDF/ Humus_Forms_ERB_31_01_2011.pdf

Zanelli R., Egli M., Mirabella A., Giaccai D., Abdelmoula M., 2007. Vegetation effects on pedogenetic forms of $\mathrm{Fe}, \mathrm{Al}$ and $\mathrm{Si}$ and clay minerals in soils in southern Switzerland and northern Italy. Geoderma 141: 119-129.

Received: January 15, 2016

Accepted: February 25, 2016 


\title{
Distribution of iron and aluminum forms as an indicator of present-day soil-forming processes in soil profiles under wooded spruce Plagiothecio-Piccetum tatricum in the Gorce Mts. (southern Poland)
}

\begin{abstract}
The aim of the study was to determine soil-forming processes in soils formed from the Magura sandstones (Carpathian flysch) under wooded spruce Plagiothecio-Piccetum tatricum in the Gorce Mts., southern Poland. The research focused on distribution of non-silicate forms of iron and aluminum in soil profiles. The content of pyrophosphate, oxalate, and dithionite phases of iron and aluminum in the genetic horizons of four soil profiles was measured and selected pedogenic factors were calculated. Based on the obtained results podzolization and brunification are dominant soil-forming processes in the studied soils. The brunification effect was more common in the soils under the large share of Athyrium distentifolium, whereas podzolization predominates in the soils where Vaccinium myrtillus prevails in forest floor. Studied soils were classified as Dystric Endoskeletic Cambisol (Loamic, Humic), Dystric Cambisol (Siltic, Humic) and Skeletic Folic Albic Podzol (Arenic).
\end{abstract}

Keywords: iron forms, aluminium forms, Cambisols, Podzols, the Gorce Mts. 